\title{
Evaluation of Acquisition of Comprehension Skills According to Whole Brain Model
}

\author{
Bünyamin Sarikaya ${ }^{1, *}$, Yusuf Söylemez ${ }^{2}$ \\ ${ }^{1}$ Department of Turkish Education, Muş Alparslan University, Muş, Turkey \\ ${ }^{2}$ Department of Turkish Education Language and Literature, İbrahim Çeçen Üniversitesi, Ağrı, Turkey
}

Copyright $\bigcirc 2018$ by authors, all rights reserved. Authors agree that this article remains permanently open access under the terms of the Creative Commons Attribution License 4.0 International License

\begin{abstract}
The aim of this study is to analyze the acquisition of comprehension skills according to the Whole Brain Model. The 50 listening and reading skills in the 2018 Turkish language teaching curriculum were examined. The study was based on qualitative research method. Data were collected using a document review and a structured and an unstructured interview form. Data were analyzed using descriptive analysis method. When necessary, reassessment was made and data were collected and reanalyzed and a comprehensive and complementary study report was prepared. While determining which brain area(s) those listening and reading skills are associated with, researchers independently codified to achieve cross-form reliability $(82 \%)$ and prepared the first draft. This draft was reviewed by 35 experts in the fields of Turkish Education, Turkish Language and Literature Education, Educational Sciences and Medicine. Experts were asked to evaluate the compliance of the items on a scale of 1 to 10 . The final draft was submitted to 12 experts in the fields of Turkish Education, Educational Sciences and Medicine who did not participate in the study before in order to establish content validity. The final decision on items with a score of less than $80 \%$ and a CVR lower than .56 was reached by conducting group discussions in line with expert opinion. According to the Whole Brain Model, 12 out of 15 listening/watching skills are associated with the upper left quadrant, 9 with the lower left quadrant and 10 with the upper right quadrant. Only 1 skill is associated with the lower right quadrant. Out of 35 reading skills, 24, 23 and 21 are associated with the upper left, lower left and upper right quadrants, respectively. Only 3 skills are associated with the lower right quadrant. These results indicate that the 2018 Turkish language teaching curriculum does not include sufficient number of skills associated with all quadrants. It is recommended that these results be taken into account when preparing the next curriculum and integrating skills into it.
\end{abstract}

Keywords Brain, Acquisition, Whole Brain Model

\section{Introduction}

Reading is one of the most important skills [1]. Reading is crucial in the development and improvement of people's mind [2]. People have many physiological, psychological and cognitive differences that add richness to humanity. "These differences among people cause differences in cognitive, emotional and kinetic responses to the same teaching method. Thus, a teaching method can promote learning for a student while is ineffective or even boring for another" [3].

The first contemporary ideas about the brain were developed in the 17th century. It was then that Francois de la Boe Sylvius described the narrow passage between the third and fourth ventricles, which was named after him as the Sylvian fissure. He also emphasized the functional importance of the brain cortex. Descartes also made a detailed description of the brain cortex and emphasized the importance of the cortex. What Descartes was actually interested in was the soul. He, later on, investigated the relation between brain and soul [4].

Individual differences depend not only on differences in brain functions and mentality, but also on differences in education and its effects on the individual. One of the most important theories that has affected the education and mentality of people in Turkey in recent years is the constructivist approach. The main objective of this approach is to provide people with the opportunity to develop the skills of questioning, thinking critically and communicating with their environment. In other words, this approach aims to enable people to develop the ability to use all parts of the brain. Here, the Whole Brain Model serves this purpose. Therefore, people who prepare curricula and integrate skills, activities and teaching techniques in them should take into account this objective.

In many aspects, the brain is no different from any other organ. Each organ has a natural function. The brain learns because that is what it is supposed to do. The brain has an almost unlimited learning capacity. Every healthy brain is equipped with a number of extraordinary qualities regardless 
of age, sex, nationality or cultural background [5]. Being unique and specific, every brain functions differently and has its own characteristics. These features make the person different from the others. Hence, when someone confronts a problem, they analyze, reason and evaluate differently depending on what part(s) of the brain they use when they perform these cognitive processes.

\section{Whole Brain Model (Herrmann's Four Quadrant Model of the Brain)}

Three brain models have been developed so far, which are;

1. Left/Right Brain Hemisphere Theory
2. Triune Brain Model
3. Whole Brain Model

Developed by Robert Ornstein and Roger Sperry, the left/right brain hemisphere theory divides the human brain into two hemispheres [6]. The left brain is responsible for processes involving high-level thinking skills such as planning, analyzing, problem solving, classifying, reasoning and speaking while the right brain is the creative side, which is the highest level of every task. Therefore, the two sides of the brain should be in harmony with each other.

This model, however, has some shortcomings. In the 1970s, Paul McLean developed the Triune Brain Model, according to which the brain consists of three parts. Only humans have the third part that is the cortex, which is responsible for cognitive function [7]. These two brain models lay the foundation for the Whole Brain Model, which is still the most valid and comprehensive model.

Hermann developed the Whole Brain Model, which divides the human brain into four distinct quadrants, which are represented by A (upper left), B (lower left), C (lower right) and $\mathrm{D}$ (upper right). $\mathrm{A}$ and $\mathrm{D}$ are mostly associated with cognition and mental processes while $\mathrm{B}$ and $\mathrm{C}$ are associated with emotional and internal organ activities [8].

Herrmann [9] uses a metaphor to describe how all parts of the brain interact with each other in the Whole Brain Model. Imagine four small chessboards with bishops, knights, rooks, and king and queen on each of them. The number of pawns on each board is equal. One of the cerebral hemispheres represents a pair of the chessboards, and the two parts of the limbic system represent the others. Since each of the four quadrants is specialized in different ways, the chess pieces are distributed based on the four quadrants of the Whole Brain Model. We need all the pieces on the boards to play chess. Containing millions of cells and hundreds of millions of connections, the brain forms pathways to perform special activities [8].

People's skills, emotions and mentalities differ. In this context, Akgul [10] pointed out the association of quadrants with skills, actions and perceptions based on the Whole Brain Model. The data in this study were grouped according to Akgul's classification.

Table 1. Association of skills, actions and perceptions with quadrants according to Whole Brain Model

\begin{tabular}{|c|c|}
\hline UPPER LEFT A (Rational) & UPPER RIGHT D (Experimental) \\
\hline $\begin{array}{l}\text { Scientific, mathematical, invention, discussion, form based problem } \\
\text { solving, analysis, constructing meaningful sentences, translation, } \\
\text { expressing, diagnosing, constructing, documenting, financial, } \\
\text { managing, technical, challenging, theorizing, rational thinking, } \\
\text { keyboard use, accounting, working alone, applying formulas, data } \\
\text { analysis, combining objects, running objects, processing numbers, } \\
\text { explaining matters, logical operations, grammatical information, } \\
\text { logic, criticism. }\end{array}$ & $\begin{array}{l}\text { Producing ideas, conducting experiments, synthesis, combining, } \\
\text { strategy building, innovation, perceiving, intuitive problem solving, } \\
\text { kinesthetic, theoretical, productive, observation, being different, } \\
\text { risky, imagining, psychological, communication, entertainment, } \\
\text { innovation, animation, conceptualism, adventurous, open to new } \\
\text { proposals, providing vision, changing, designing, producing } \\
\text { solutions, comprehension, imagination, dream, emplotment, } \\
\text { animation, the ability to grasp the whole, artistic skill, poem, art }\end{array}$ \\
\hline LOWER LEFT B (Safekeeping) & LOWER RIGHT C (Feeling) \\
\hline $\begin{array}{l}\text { Psychomotor skills, planning, scheduling, implementation, ranking, } \\
\text { organizing, detailed, mechanical, repair, legal, agricultural, } \\
\text { administrative, military, the ability to assemble, civil service, } \\
\text { methodical, controlling, disciplined, authority, concrete, developing } \\
\text { policies, filing, providing security, word processing, applying } \\
\text { procedures, creating objects, being controlled, status quo, sorting, } \\
\text { planning, stability, doing work on time, focusing on details, } \\
\text { structured tasks, management, eurhythmics, organizing skill, making } \\
\text { inferences, listing, sarcastic attitudes towards new ideas, } \\
\text { conservatism, defense, protection, tendency to violence, school and } \\
\text { work etc. }\end{array}$ & $\begin{array}{l}\text { Expression, tactile, interpersonal communication, music-lover, } \\
\text { understanding people, feeling, social, caring, helping, teaching, } \\
\text { comforting, growing, supporting, improving, consultancy, } \\
\text { coordination, writing, comprehending, explaining ideas, participant, } \\
\text { education, thinking, speaking, persuading, helping people, } \\
\text { explanatory text, consultancy, musical talent, emphasis, melody, } \\
\text { toning, speaking fluently, ability of persuasion, coding, avoiding } \\
\text { being judgmental, passions }\end{array}$ \\
\hline
\end{tabular}

Table 1 shows that the upper left quadrant is associated with high-level thinking skills for analysis, discussion and clarification. The lower right quadrant is associated with melody, emphasis, intonation and persuasion, which are critical in speaking skills. The upper right quadrant is associated with emotional-based skills such as comprehension, animation, poetry, dream and psychological perception. Lastly, the lower left quadrant is associated with psychomotor skills such as organizing, sequencing and planning.

Another noteworthy point is that all four quarters are associated with language-based skills (expressing openly, criticism, poetry, word processing, melody, intonation). It is evident that the brain acts as a whole in language-based processes. 
A noteworthy aspect of Table 1 is that each quadrant corresponds to a personality structure, hence the classification; Rational (upper left A), Safekeeping (lower left B), Experimental (upper right D) and Feeling (lower right $\mathrm{C}$ ). The sections and their features show that there is a healthy relationship between quadrants and personality structures.

The main aim of this study is to examine the acquisition of comprehension skills (listening, reading) related to the 2018 Turkish language teaching curriculum according to the Whole Brain Model classified above.

\section{Method}

This study was conducted according to qualitative research approach, which provides an opportunity to conduct an in-depth investigation on a subject matter. It is important that data is collected and analyzed using more than one method and that data support each other in terms of validity and reliability. Therefore, document review and interview were the methods of choice in this study.

\subsection{Data Collection and Analysis}

Two types of data were collected using document review and interview methods.

The skills related to the 2018 Turkish language teaching curriculum and their classification, were carried out using the document review method according to the Whole Brain Model. Yildirim and Şimşek [11] state that document review is a method used by historians, anthropologists and linguists to examine and analyze written materials containing information about cases or phenomena.

During data collection, first, reading and listening skills related to the fifth-, sixth-, seventh- and eighth- grade Turkish language teaching curriculum were determined. Those skills were compared to the brain mapping functions in the Whole Brain Model developed by Ned Herrmann and analyzed according to the diagram compiled by Akgül [10]. During analysis, we determined which brain quadrant(s) is associated with reading, listening and learning skills. The skills were coded for four quadrants by two independent researchers, and the cross-forms were compared using the reliability technique. According to Miles and Huberman [12], when two researchers code use the same set of data, definitions become more accurate. Disagreements suggest that definitions should be expanded or corrected. Inter-encoder reliability ratio can be calculated by dividing the number of consensus codes by the total number of consensus and non-consensus codes. Initially, inter-encoder reliability is not expected to be higher than $70 \%$. It is, however, recommended that the ratio be close to $80 \%$, even more than $90 \%$ of the size of the data [12]. After three rounds of coding, $82 \%$ consensus was achieved and 35 experts in the fields of Turkish Education, Turkish Language and Literature Education, Educational Sciences and Medicine were asked to evaluate the compliance of the items on a scale of 0 to 10 . Face-to-face interviews were conducted using the focus interview technique for items with a compliance score below $80 \%$, and unstructured interview form was used during interviews. The data were analyzed, and 12 experts in the fields of Turkish Education, Educational Sciences and Medicine and who were not involved in the study were consulted in order to establish the content validity of the draft. Lawshe's content validity ratio was used to determine the content validity [13]. Focus interviews were conducted with medical specialists for the items with a CVR of less than 0.56, and comprehension skills related to the 2018 Turkish language teaching curriculum were classified according to the Whole Brain Model based on the analysis of the data.

The data were analyzed descriptively. According to descriptive analysis approach, data are summarized and interpreted according to previously determined themes. Data can either be organized according to themes set out by research questions or can be presented taking into account questions or dimensions used in interviews and observation processes [11].

\section{Findings}

In this section, we will address the findings including the classification of the comprehension skills related to the 2018 Turkish language teaching curriculum according to the Whole Brain Model. We will determine which quadrant(s) is associated with the skills. Expert opinion shows that only one quadrant is associated with some skills while multiple quadrants are associated with some others.

\subsection{Classification of Listening/Watching Skills by Whole Brain Model}

The curriculum has a total of 15 listening/watching skills.

\section{Listening/Watching Skills Associated with Upper Left Quadrant}

Table 2. Listening/Watching Skills Associated with Upper Left Quadrant

\begin{tabular}{r|l|c|c}
\hline & Regarding audial and visual inputs & $\begin{array}{c}\text { Expert } \\
\text { Opinion }\end{array}$ & CVR \\
\hline 1. & $\begin{array}{l}\text { Making assumptions about the } \\
\text { development and conclusion of } \\
\text { events }\end{array}$ & $80 \%$ & 0.83 \\
\hline 2. & Guessing the meaning of words & $95 \%$ & 1.00 \\
\hline 3. & $\begin{array}{l}\text { Identifying the main idea/main } \\
\text { feeling }\end{array}$ & $95 \%$ & 1.00 \\
\hline 4. & Summarizing & $80 \%$ & 1.00 \\
\hline 5. & Answering questions & $\mathbf{7 0 \%}$ & $\mathbf{0 . 5 0}$ \\
\hline 6. & Suggesting different titles & $\mathbf{7 5 \%}$ & 0.67 \\
\hline 7. & Recognizing non-verbal messages & $85 \%$ & 0.67 \\
\hline 8. & Evaluating the content & $90 \%$ & 1.00 \\
\hline 9. & Expressing opinions & $\mathbf{7 5 \%}$ & $\mathbf{0 . 5 0}$ \\
\hline 10. & $\begin{array}{l}\text { Identifying ways of developing the } \\
\text { applied idea }\end{array}$ & $95 \%$ & 0.83 \\
\hline 11. & Questioning the consistency & $95 \%$ & 1.00 \\
\hline 12. & Evaluating media texts & $85 \%$ & 1.00 \\
\hline
\end{tabular}


Table 2 shows that the upper left quadrant was associated with 12 of the 15 listening/watching skills. Expert opinion is expected to have a consensus of $80 \%$ and over while the lowest CVR determined by 12 experts in is expected to be at least .56. It was observed that items 5, 6 and 9 were problematic, and therefore, a focus interview was conducted to decide if those items were to be moved to a different quadrant. Due to the complexity of the brain, there was a consensus that such abstract issues cannot be solved easily. Therefore, it was concluded that items 5 and 9 should be classified into another quadrant. Some experts stated that the lower left and right upper quadrants were associated with items 5 and 9 , and that they should be assessed in those quadrants. Again, based on expert opinion and CVR value, item 6 was not replaced to another quadrant.

The fact that the upper left quadrant was associated with 12 of the 15 skills is problematic because, ideally, those skills should be equally distributed among the quadrants. What part(s) of the brain people use depends on individual differences. It can be stated that the acquisitions in Table 2 are associated with high-level thinking skills such as analysis, rational thinking, critical thinking and logical operations.

\section{Listening/Watching Skills Associated with Lower Left Quadrant}

The listening/watching skills associated with the lower left quadrant are as follows:

Table 3. Listening/watching skills associated with lower left quadrant

\begin{tabular}{r|l|c|c}
\hline & $\begin{array}{l}\text { Regarding audial and visual } \\
\text { inputs }\end{array}$ & $\begin{array}{c}\text { Expert } \\
\text { Opinion }\end{array}$ & CVR \\
\hline 1. & $\begin{array}{l}\text { Making assumptions about the } \\
\text { development and conclusion of } \\
\text { events }\end{array}$ & $80 \%$ & 1.00 \\
\hline 2. & Summarizing & $80 \%$ & 1.00 \\
\hline 3. & Answering questions & $90 \%$ & 1.00 \\
\hline 4. & Suggesting different titles & $90 \%$ & 1.00 \\
\hline 5. & Recognizing non-verbal messages & $\mathbf{6 5 \%}$ & $\mathbf{0 . 5 0}$ \\
\hline 6. & Evaluating the content & $80 \%$ & 0.83 \\
\hline 7. & Expressing opinions & $80 \%$ & 0.83 \\
\hline 8. & Applying listening strategies & $95 \%$ & 1.00 \\
\hline 9. & Questioning the consistency & $\mathbf{7 5 \%}$ & 0.83 \\
\hline 10. & Evaluating media texts & $95 \%$ & 0.83 \\
\hline
\end{tabular}

Table 3 shows that the lower left quadrant was associated with 10 of the 15 listening/watching skills. The rates indicate that items 5 and 9 were problematic. The level of consensus of the experts on item 5 was low and its CVR was lower than .50 , and therefore, it fell outside the content validity. As a result of the focus interviews, it was concluded that it would be appropriate to evaluate item 5 in the lower right quadrant. Based on expert opinion, item 9 was evaluated in the lower left quadrant although the expert consensus was below $80 \%(75 \%)$, because its content validity score was sufficient ( $\mathrm{CVR}=0.83$ ).

The expert opinion shows that the lower left quadrant was associated with 10 of the 15 listening/watching skills. These are skills such as sorting, organizing, planning and reasoning in which mind should be actively involved.

\section{Listening/Watching Skills Associated with Upper Right Quadrant}

The listening/watching skills associated with the upper right quadrant are as follows:

Table 4. Listening/watching skills associated with upper right quadrant

\begin{tabular}{r|l|c|c}
\hline & Regarding audial and visual inputs & $\begin{array}{c}\text { Expert } \\
\text { Opinion }\end{array}$ & CVR \\
\hline 1. & $\begin{array}{l}\text { Making assumptions about the } \\
\text { development and conclusion of events }\end{array}$ & $80 \%$ & 0.67 \\
\hline 2. & Guessing the meaning of words & $95 \%$ & 1.00 \\
\hline 3. & Detecting the subject & $95 \%$ & 1.00 \\
\hline 4. & Identifying the main idea/main feeling & $90 \%$ & 1.00 \\
\hline 5. & Summarizing & $80 \%$ & 0.83 \\
\hline 6. & Answering questions & $90 \%$ & 1.00 \\
\hline 7. & Suggesting different titles & $80 \%$ & 0.67 \\
\hline 8. & Evaluating the content & $\mathbf{7 5 \%}$ & 0.83 \\
\hline 9. & Portraying narrative texts & $95 \%$ & 1.00 \\
\hline 10. & Expressing opinions & $95 \%$ & 1.00 \\
\hline & & &
\end{tabular}

Table 4 shows that the upper right quadrant was associated with 10 of the 15 listening/watching skills. The expert opinion and CVR values of these skills were high, except for item 8 , which had $75 \%$ of expert consensus. However, its CVR score was high $(0.83>.56)$, and therefore, it was evaluated in this quadrant.

These skills corresponding to the upper right quadrant are acquisitions such as generating ideas, synthesizing, conceptualizing, generating solutions and visualizing which not only require high-level thinking skills but also develop psychomotor skills.

\section{Listening/Watching Skills Associated with Lower Right Quadrant}

The listening/watching skills associated with the lower right quadrant are as follows:

Table 5. Listening/watching skills associated with lower right quadrant

\begin{tabular}{c|l|c|c}
\hline & & $\begin{array}{c}\text { Expert } \\
\text { Opinion }\end{array}$ & CVR \\
\hline 1. & $\begin{array}{l}\text { Comprehending the non-verbal } \\
\text { messages of the speaker }\end{array}$ & $80 \%$ & 0.67 \\
\hline
\end{tabular}

Table 5 shows that the lower right quadrant was associated with only one listening/watching skill. However, its expert consensus was $80 \%$ and CVR .67, therefore no change was made.

This result is very problematic because the lower right quadrant is responsible for the development of socially necessary acquisitions such as feeling, expressing emotions and opinions, interpersonal communication, and understanding and helping others. Students are expected to develop these acquisitions, however, the fact that the lower right quadrant was found to be associated with only one listening/watching skill shows that it is hardly the case. 


\subsection{Classification of Reading Skills by Whole Brain Model}

The curriculum has 35 reading skills.

\section{Reading Skills Associated with Upper Left Quadrant}

The reading skills associated with the upper left quadrant are as follows:

Table 6. Reading skills associated with upper left quadrant

\begin{tabular}{|c|c|c|c|}
\hline & & Expert Opinion & CVR \\
\hline 1. & Using the context to predict the meaning of unknown words and phrases & $95 \%$ & 1.00 \\
\hline 2. & Summarizing a text & $90 \%$ & 1.00 \\
\hline 3. & Determining the main idea/main feeling of a text & $95 \%$ & 1.00 \\
\hline 4. & Determining the narrative elements of a text & $90 \%$ & 1.00 \\
\hline 5. & Interpreting the content of a text & $65 \%$ & 0.50 \\
\hline 6. & Asking questions about a text & $95 \%$ & 0.83 \\
\hline 7. & Answering questions about a text & $65 \%$ & 0.50 \\
\hline 8. & Predicting the subject of a text from its images and title & $90 \%$ & 1.00 \\
\hline 9. & Answering questions about the images in a text & $75 \%$ & 0.50 \\
\hline 10. & Recognizing the key points of a text & $95 \%$ & 1.00 \\
\hline 11. & Finding a title or titles appropriate to the content of a text & $95 \%$ & 1.00 \\
\hline 12. & Evaluating media texts & $95 \%$ & 1.00 \\
\hline 13. & $\begin{array}{l}\text { Understanding the contribution of the transitions and connections between the elements } \\
\text { of a text to the meaning }\end{array}$ & $95 \%$ & 1.00 \\
\hline 14. & Comparing texts & $95 \%$ & 1.00 \\
\hline 15. & Using information resources effectively & $85 \%$ & 0.83 \\
\hline 16. & Questioning the reliability of information sources & $85 \%$ & 0.83 \\
\hline 17. & Distinguishing real and fictional elements in a text & $85 \%$ & 1.00 \\
\hline 18. & Making inferences about a text & $95 \%$ & 1.00 \\
\hline 19. & Distinguishing the literal, metaphorical and terminological use of words in a text & $75 \%$ & 0.67 \\
\hline 20. & Answering questions about information presented on a chart, graph or table & $75 \%$ & 0.50 \\
\hline 21. & Describing the stylistic features of a poem & $90 \%$ & 0.67 \\
\hline 22. & Detecting the semantic properties of verbs & $95 \%$ & 0.67 \\
\hline 23. & Identifying the secondary themes in a text & $95 \%$ & 0.83 \\
\hline 24. & Comparing the written text and media presentation of a literary work & $90 \%$ & 1.00 \\
\hline 25. & Determining the forms of expression in a text & $95 \%$ & 1.00 \\
\hline 26. & Determining the ways of developing a thought in a text & $90 \%$ & 0.83 \\
\hline 27. & Understanding the process steps in a text & $85 \%$ & 0.67 \\
\hline 28. & Interpreting information presented on a chart, graph or table & $80 \%$ & 0.83 \\
\hline
\end{tabular}

Table 6 shows that the upper left quadrant was associated with 28 of the 35 reading skills. The expert consensus on items 5 , 7, 9, 19 and 20 was below 80\%. Only item 19 had a high content validity (CVR $=, 67>56)$, therefore, all items except 19 was evaluated in the upper left quadrant.

This result shows that the upper left quadrant is associated with the majority of the reading skills such as deciphering, making meaningful sentences, expressing clearly, explaining topics and analyzing. 


\section{Reading Skills Associated with Lower Left Quadrant}

The reading skills associated with the lower left quadrant are as follows:

Table 7. Reading skills associated with the lower left quadrant

\begin{tabular}{|c|c|c|c|}
\hline & & $\begin{array}{c}\text { Expert } \\
\text { Opinion } \\
\end{array}$ & CVR \\
\hline 1. & Reading a text in line with its genre & $80 \%$ & 0.83 \\
\hline 2. & Using reading strategies & $95 \%$ & 1.00 \\
\hline 3. & Distinguishing text types & $95 \%$ & 1.00 \\
\hline 4. & Summarizing a text & $80 \%$ & 1.00 \\
\hline 5. & Interpreting a text & $80 \%$ & 0.83 \\
\hline 6. & Asking questions about a text & $90 \%$ & 0.67 \\
\hline 7. & Answering questions about a text & $90 \%$ & 1.00 \\
\hline 8. & $\begin{array}{l}\text { Predicting the subject of a text from } \\
\text { its images and title }\end{array}$ & $90 \%$ & 1.00 \\
\hline 9. & $\begin{array}{l}\text { Answering questions about the } \\
\text { images in a text }\end{array}$ & $95 \%$ & 1.00 \\
\hline 10. & Recognizing the key points of a text & $95 \%$ & 0.83 \\
\hline 11. & $\begin{array}{l}\text { Finding a title or titles appropriate to } \\
\text { the content of a text }\end{array}$ & $95 \%$ & 1.00 \\
\hline 12. & Evaluating media texts & $85 \%$ & 1.00 \\
\hline 13. & $\begin{array}{l}\text { Understanding the contribution of } \\
\text { the transitions and connections } \\
\text { between the elements of a text to the } \\
\text { meaning }\end{array}$ & $90 \%$ & 1.00 \\
\hline 14. & Comparing texts & $85 \%$ & 0.83 \\
\hline 15. & $\begin{array}{l}\text { Using information resources } \\
\text { effectively }\end{array}$ & $90 \%$ & 1.00 \\
\hline 16. & $\begin{array}{l}\text { Questioning the reliability of } \\
\text { information sources }\end{array}$ & $95 \%$ & 1.00 \\
\hline 17. & $\begin{array}{l}\text { Distinguishing real and fictional } \\
\text { elements in a text }\end{array}$ & $95 \%$ & 0.83 \\
\hline 18. & Making inferences about a text & $95 \%$ & 1.00 \\
\hline 19. & $\begin{array}{l}\text { Interpreting information presented } \\
\text { on a chart, graph or table }\end{array}$ & $85 \%$ & 0.67 \\
\hline 20. & $\begin{array}{l}\text { Detecting the semantic properties of } \\
\text { verb }\end{array}$ & $95 \%$ & 0.83 \\
\hline 21. & $\begin{array}{l}\text { Comparing the written text and } \\
\text { media presentation of a literary } \\
\text { work }\end{array}$ & $90 \%$ & 0.83 \\
\hline 22. & $\begin{array}{l}\text { Answering questions about } \\
\text { information presented on a chart, } \\
\text { graph or table }\end{array}$ & $90 \%$ & 1.00 \\
\hline 23. & $\begin{array}{l}\text { Describing the stylistic features of a } \\
\text { poem }\end{array}$ & $90 \%$ & 0.67 \\
\hline
\end{tabular}

Table 7 shows that the lower left quadrant was associated with 23 of the 35 reading skills. None of the items had an expert consensus lower than $80 \%$ and CVR lower than .56, therefore, no change was made.

The fact that the lower left quadrant is associated with 23 of the 35 reading skills is a positive result. Reading skills provide students with the opportunity to acquire psychomotor skills such as sorting, organizing, word processing, planning, and relating or describing in detail. The reading skills acquisitions in Table 7 also include these psychomotor skills.

\section{Reading Skills Associated with Upper Right Quadrant}

The reading skills associated with the upper right quadrant are as follows:

Table 8. Reading skills associated with upper right quadrant

\begin{tabular}{|c|c|c|c|}
\hline & & $\begin{array}{l}\text { Expert } \\
\text { Opinion } \\
\end{array}$ & CVR \\
\hline 1. & $\begin{array}{l}\text { Using the context to predict the } \\
\text { meaning of unknown words and } \\
\text { phrases }\end{array}$ & $90 \%$ & 0.83 \\
\hline 2. & $\begin{array}{l}\text { Determining the main idea/main } \\
\text { feeling of a text }\end{array}$ & $95 \%$ & 1.00 \\
\hline 3. & Summarizing a text & $95 \%$ & 1.00 \\
\hline 4. & Distinguishing text types & $80 \%$ & 0.63 \\
\hline 5 . & $\begin{array}{l}\text { Finding different solutions to } \\
\text { problems addressed in a text }\end{array}$ & $80 \%$ & 0.50 \\
\hline 6. & $\begin{array}{l}\text { Identifying the narrative elements in } \\
\text { texts }\end{array}$ & $85 \%$ & 0.67 \\
\hline 7. & Interpreting the content of a text & $85 \%$ & 0.83 \\
\hline 8. & Asking questions about a text & $90 \%$ & 1.00 \\
\hline 9. & Answering questions about a text & $85 \%$ & 0.83 \\
\hline 10. & $\begin{array}{l}\text { Predicting the subject of a text from } \\
\text { its images and title }\end{array}$ & $95 \%$ & 0.83 \\
\hline 11. & $\begin{array}{l}\text { Finding a title or titles appropriate to } \\
\text { the content of a text }\end{array}$ & $95 \%$ & 1.00 \\
\hline 12. & $\begin{array}{l}\text { Understanding the contribution of } \\
\text { the transitions and connections } \\
\text { between the elements of a text to the } \\
\text { meaning }\end{array}$ & $85 \%$ & 1.00 \\
\hline 13. & Comparing texts & $90 \%$ & 1.00 \\
\hline 14. & Making inferences about a text & $85 \%$ & 0.83 \\
\hline 15. & $\begin{array}{l}\text { Detecting the semantic properties of } \\
\text { verbs }\end{array}$ & $95 \%$ & 0.67 \\
\hline 16. & $\begin{array}{l}\text { Interpreting information presented } \\
\text { on a chart, graph or table }\end{array}$ & $95 \%$ & 0.83 \\
\hline 17. & $\begin{array}{l}\text { Comparing the written text and } \\
\text { media presentation of a literary work }\end{array}$ & $95 \%$ & 0.83 \\
\hline 18. & $\begin{array}{l}\text { Determining the forms of expression } \\
\text { in a text }\end{array}$ & $95 \%$ & 0.67 \\
\hline 19. & $\begin{array}{l}\text { Determining the ways of developing } \\
\text { thought in a text }\end{array}$ & $95 \%$ & 0.67 \\
\hline 20. & $\begin{array}{l}\text { Understanding the process steps in a } \\
\text { text }\end{array}$ & $95 \%$ & 0.83 \\
\hline 21. & Identifying auxiliary ideas in a text & $95 \%$ & 1.00 \\
\hline
\end{tabular}

Table 8 shows that the upper right quadrant was associated with 21 of the 35 reading skills. None of the items had an expert consensus lower than $80 \%$ and CVR lower than .56, therefore, no change was made.

Reading skills provide people with further skills such as generating new ideas, synthesizing, interpreting visuals, imagining, being productive, designing and comprehending. It is, therefore, a positive outcome that the upper right quadrant was associated with 21 of the 35 reading skills.

\section{Reading Skills Associated with Lower Right Quadrant}

The reading skills associated with the lower right quadrant are as follows: 
Table 9. Reading skills associated with lower right quadrant

\begin{tabular}{c|l|c|c}
\hline & & $\begin{array}{c}\text { Expert } \\
\text { Opinion }\end{array}$ & CVR \\
\hline 1. & $\begin{array}{l}\text { Reading silently or out loud and } \\
\text { paying attention to punctuation }\end{array}$ & $80 \%$ & 0.83 \\
\hline 2. & Reading a text in line with its genre & $95 \%$ & 1.00 \\
\hline 3. & $\begin{array}{l}\text { Read texts written in different } \\
\text { typefaces }\end{array}$ & $95 \%$ & 1.00 \\
\hline 4. & $\begin{array}{l}\text { Determining the ways of developing } \\
\text { thought in a text }\end{array}$ & $\mathbf{6 5 \%}$ & $\mathbf{0 . 5 0}$ \\
\hline
\end{tabular}

Table 9 shows that the lower right quadrant was associated with 4 of the 35 reading skills. Expert consensus on item 4 was $65 \%$ and CVR was .50. Therefore, a focus interview was conducted and 4 items was evaluated in the lower right quadrant.

The lower right quadrant is associated with the fewest reading skills as with the listening/watching skills. Yet, it is the lower right quadrant which is responsible for thinking, speaking, persuading, teaching and coding skills that students should possess. This is unfortunately a result of shortsightedness on the part of those who developed the curriculum.

\section{Conclusion and Discussion}

Knowledge is synonymous to awareness, learning, education and cognizance. Knowledge as to do with understanding; and understanding is based on the quality of information acquire at a time on a precise subject matter [14].

The structure and function of each brain is different. High-level thinking is one of the main tasks of the brain. There are many studies that emphasize the importance of high level thinking skills in human life and explaining the

Whole Brain Model (Lee [16]; Söylemez [18]; Dadig [19]; Yıldırım \& Haşılığlu [20] ; De Boer, Steyn \& du Toit [15]; Yıldırım, Akman \& Alagöz [21]; Sevim [22]; De Boer [23]; Söylemez [24]; Temizyürek\&Bulut [25]; Wilson [17]; Sarikaya [26]; Topçu [27]; Mitits [28].

Dadig [19] investigated whether brain dominance factors played a role in the evaluation of student performance, and correlated the Herrmann Brain Dominance Instrument (HBDI) results with the clinical competence-based assessment of students to determine the relationship between brain dominance and student performance. The results showed that there was a significant relationship between students' cognitive style profiles and instructional behaviors. De Boer [23] determined that the HBDI Model could be a valid and useful diagnostic evaluation for determining students' thinking priorities (learning styles). The results of this design study are consistent with those of Hermann's study.

Bentley [29] prepared a cognitive intellectual learning questionnaire based on expert opinion to explain the meaning and theoretical interpretations of the HBDI. The research included the relationship between the questionnaire and the HBDI and the results of right, left and whole brain.
The results of the study showed that individual differences are important in learning. De Boer, Steyn and Du Toit [15] used the HBDI to investigate the thinking profiles of adult students in South Africa. The results showed that differences in thinking quadrants play an important role in students' preferences.

Lee [16] investigated the effect of whole brain education on academic achievement, attitudes and retention in accounting courses of three academic vocational high schools in central Taiwan. The results indicated a significant difference in achievement levels between the experimental and control groups in favor of the former.

Wilson [17] analyzed the relationship between the HBDI and a thinking preference assessment tool and a behavior preference assessment tool. Analysis results showed that the relationships between thinking and behavior were identifiable.

This study assessed the comprehension skills related to the 2018 Turkish language teaching curriculum according to the Whole Brain Model, and examined a total of 50 skills individually. It should not be ruled out that some of the skills are associated with more than one quadrant. Data from expert opinion were evaluated and interpreted. It should be highlighted that the findings of this study are not experimentally proven. This is, therefore, only a preliminary study that paves the way for further experimental research.

According to the Whole Brain Model, 12 out of 15 listening/watching skills are associated with the upper left quadrant, 9 with the lower left quadrant and 10 with the upper right quadrant. Only 1 skill is associated with the lower right quadrant. There are very few skills associated with the lower right quadrant. Akgül [10] reported that the fewest listening skills related to the 2006 Turkish language teaching curriculum are associated with the lower right quadrant. Therefore, the result of this study is similar to that reported by Akgül. While the number of skills associated with the three quadrants (upper left, lower left and upper right) is similar, the number of skills associated with the lower right quadrant is low, indicating that the exclusion of the lower right quadrant from the curriculum causes students not to be able develop the skills associated with it [10].

Out of 35 reading skills, 24, 23 and 21 are associated with the upper left, lower left and upper right quadrants, respectively. Only 3 skills are associated with the lower right quadrant. Akgül [10] reported that only 8 reading skills related to the 2006 Turkish language teaching curriculum are associated with the lower right quadrant, which is consistent with the result of this study. It is an important manifestation of how unevenly distributed the reading skills are in the brain. In this case, it would be very difficult for students to develop skills associated with the lower right quadrant.

The results show that the highest number of skills is associated with the upper quadrants. The classification shows that the number of both reading and listening/watching skills associated with the lower right quadrant is very small. Onan and Akgül [6] emphasized the 
importance of the lower right quadrant especially in communication skills. Given that the Turkish language teaching curriculum prepares students for life, the inadequate and unbalanced distribution of the lower right quadrant in the curriculum defeats the purpose of the curriculum itself. Students should pay attention to expressing themselves, improving social skills, making fluent speeches, emphasis, melody and toning, especially in interpersonal communication. It is of paramount significance that students develop these skills. However, the results indicate that the skills related to the 2018 Turkish language teaching curriculum are unevenly distributed.

The results of this study are similar to those reported by Akgül [10]. This might be due to three reasons: First, both 2006 and 2018 Turkish language teaching curricula were prepared based on constructivist approach. Second, both curricula include acquisitions with the same content. Third, both curricula were prepared by the same institution and people.

What differentiates this study from that of Akgül [10] is that there is a big time gap between the preparation/implementation of the two curricula? Further research can, therefore, focus on comparing the two curricula and pointing out their differences and similarities. Besides, some of the results of this study are different from those reported by Akgül [10]. In this study, reading and listening skills were found to be associated with the upper left quadrant while Akgül [10] reported that it was the upper right quadrant with which those skills were predominantly associated.

Reading and listening skills should also be used in language teaching because they definitely play a key role in native language and foreign language acquisition. Reading skills enable students to learn grammar and vocabulary while listening/watching skills enable them to comprehend the practical aspects of language.

In conclusion, further experimental research should be conducted on this subject matter, speaking-writing skills in the 2018 Turkish Language Teaching curriculum [30] should be addressed in this regard and more skills associated with the lower right quadrant should be included in the curriculum that will be prepared in the coming years.

\section{REFERENCES}

[1] Migdadi, A. İ.M. and A., Baniabdelrahman, (2016). The effect of using team teaching on jordanian efl eleventh grade students' reading comprehension and their attitudes towards this strategy. Journal of Education and e-Learning Research, 3(2): $38-50$.

[2] Oriogu, C. D. (2015). Catch them young: developing and 1mproving of school libraries and reading habit of secondary school students in Nigeria. Journal of Education and e-Learning Research Vol. 2, No. 4: 60-63.

[3] Açıkgöz, K. Ü. (2007). Effective learning and teaching. İzmir:
Biliş Publishing.

[4] Smith, A. (1986). Human brain and life. (Transl. by Necat Ebcioğlu), İstanbul: İnkılâp Publishing.

[5] Caine, R. N. and Caine G. (2002). Making connections: teaching and the human brain. (Transl. by Ülken, G). Ankara: Nobel Publishing.

[6] Onan, B. and G. Akgül, (2012). Evaluation of acquisitions in the turkish language teaching curriculum in relation to Ned Herrmann's holistic brain model. CU Journal of Social Sceinces. 36(1): 111139.

[7] Sezik, N. (2003). Unlimited brain power. İstanbul: Hayat Publishing.

[8] Herrmann N., Nehdi, A. (2002). Training With The Brain In Mind: The Application of brain dominance technology to teaching and learning. Session Number 509, http://www.hbdi.com/docs/training_with_brain.pdf.

[9] Herrmann, N. (2003). The whole brain business book. İstanbul: Hayat Publishing.

[10] Akgül, G. (2010). To analyze and be classified the listenıng, reading, writıng, speaking acquisitions in the learning fields which takes place in Turkish teaching (1n the 6th, 7th, 8th grades) curriculum of 2006 in primary education according to the 'brain dominance model'. Unpublished Master's Thesis, Mustafa Kemal University, Hatay.

[11] Yıldırım, A. and H. Şimşek, (2000). Qualitative research methods in social sciences. Ankara: Seçkin Publishing.

[12] Huberman, A. M., \& Miles, M. B. (1994). Qualitative data Analysis: an expanded source book. ( ${ }^{\text {nd }}$ Edition). Calif.: Sage Publishing.

[13] Lawshe, C. H. (1975). A Quantitative Approach to Content Validity. Personnel Psychology, 28, 563-575.

[14] Adeyemi Stephen, B., Funmilayo Roseline, O. and Ocheje, C. B. (2015). Effective knowledge development in secondary schools educational level in contemporary information age: assessment of availability of electronic information resources in Nigerian school libraries. Journal of Education and e-Learning Research Vol. 2, No. 4: 72-78.

[15] De Boer, A.L., Steyn, T. and Du Toit, P. H. (2001). A whole brain approach to teaching and learning in higher education. South African Journal of Higher Education, v15 n3 p185-93.

[16] Lee L.T. (2005). Academic achievement, attitudes, and retention: application of whole brain instruction in the principles of accounting course in central Taiwan. Ph. D. Thesis, Idaho State University.

[17] Wilson D.H. (2007). A comparison of the Herrmann's brain dominance instrument (tm) and the extended discrtm behavior profiling tool: an attempt to create a more discerning management perspective. Ph. D. Thesis, Capella University.

[18] Söylemez, Y. (2016). Content analysis: critical thinking. EKEV Academic Journal. 20(66): 671-696

[19] Dadig, B.A.S. (1996). The role of brain dominance in student evaluation and perception of clinical preceptor effectiveness in the preparation of physician assistants. Ed. D. Thesis, University of Georgia.

[20] Yildirim, S. and M.A. Haşılıoğlu. (2018). Analysis of 
scientific research related anxiety levels of undergraduate students'. Universal Journal of Educational Research 6(2): 313-316.

[21] Yildirim, S., Ö. Akman and B. Alagöz, (2017). The level of history teachers' using active learning methods and technics. International Education Studies. 10(12): 140-152.

[22] Sevim, O. (2014). Effects of drama method on speaking anxieties pre service teachers and their opinions about the method. Educational Research and Reviews (18): 734-742

[23] De Boer A.L. (2001). The value of the Herrmann's brain dominance instrument (hbd1) in facilitating effective teaching and learning of criminology. Acta Criminologica Vol 14(1).

[24] Söylemez, Y. (2015). Developing scales for critical basic language skills intended for secondary school students. Unpublished Doctoral Thesis. Atatürk University, Erzurum.

[25] Temizyürek, F. and K. Bulut, (2016). The importance of creative writing in the language development of child. YYU Journal of Education Faculty 3(1): 146-163.
[26] Sarikaya, B. (2016). The effects of visuals configured according to levels of problem solving on writing skills and attitudes of the hearing impaired students at 6th, 7th and 8th grades. Unpublished Doctoral Thesis. Atatürk University, Erzurum.

[27] Topçu, E. (2017). How do the teachers define social studies course? Journal of Education and e-Learning Research, 4(4): 139-153.

[28] Mitits, L. (2017). Multilingual students in greek schools: teachers ${ }^{\text {ee }}$ views and teaching practices. Journal of Education and e-Learning Research, 5(1). 28-36.

[29] Bentley J.P.H. (2001). Learning orientation questionnaire correlation with the Herrmann brain dominance instrument. Ph. D. Thesis, Brigham Young University.

[30] MEB. (2018). The 2018 Turkish language teaching curriculum. Ankara: Milli Eğitim Publishing. 